\title{
Motivation to Learn and its Relationship to Academic Achievement among Students of basic Arabic Schools in China
}

\author{
Abdo Hasan AL-Qadri \\ School of Education- Shaanxi Normal University, Xi'an 710062, P.R. China \\ Email: lubna23112015@outlook.com \\ Zhao Wei \\ School of Education- Shaanxi Normal University, Xi'an 710062, P.R. China \\ Email: zhaowei@snnu.edu.cn
}

Received: 29 December 2018; Accepted: 20 January 2019; Published: 08 April 2019

\begin{abstract}
This correlational study examined the effects of motivation in the process of learning and its connections to the academic achievement of the students who study at the Basic Arabic Schools in China. The designed tool, which is a questionnaire, consists of 40 items and had been processed by statistical analysis to contrived psychometric properties and it had been achieved through validity and reliability. The study acknowledged the cumulative scores of academic achievement of students for the last academic year, which was considered as one of the variables of the current study and compared to motivation to learn in the questionnaire sample of 30 students as well as the sample of the final study which covered all 242 students in the basic Arabic schools of the $7^{\text {th }}, 8^{\text {th }}$ and $9^{\text {th }}$ Grades. The study found that there was a significant correlation between motivation to learn and academic achievement of students. It was proved through correlation and regression analysis that there was a positive relationship between motivation and academic achievement and the ability to predict the academic achievement through motivation. It had been found that the most motivated students are the ones who achieve higher academic performance. There were significant differences in motivation according to the gender in which females scored the highest means. Besides, no significant differences found in grade variables.
\end{abstract}

Index Terms - Academic achievement; motivation to learn; relationship; correlation

\section{INTRODUCTION}

Many educators suffer from non- willingness of students to learn [1].This in turn worries educators because it eventually leads to low academic achievement, as it is our main concern to shed light on some aspects through which we can identify the level of students' academic achievement $[2,3]$

Motivation to learn is considered to be greatly important, as it is a prerequisite for the success of the educational process $[4,5]$. It helps and moves students to achieve and accomplish, contributes in increasing efforts, energy, initiative, and perseverance of students, and it increases their ability to process information, which is reflected on their performance in the classroom, and this in turn leads to raising students interaction in the classroom and their academic achievement [6].

Clement, Dornyei and Noels [7] added that motivation is considered to be an effective learning factor that encourages students in their educational activities and leads to enabling them to choose the activity model that they desire to perform. Thus, it is a must to assist students in creating their motivation for learning what should be learnt [8]. Students should be also guided to realize the significance of their educational activities in order to be successful in their academic achievement $[9,10]$.

\section{A. Definition of Motive}

Motive can be defined as a group of internal conditions that move individuals to fill a certain deficiency or need, whether biological, psychological or social [11]. Thus, the concept of motive is related to the concept of need, as need indicates change, decrease, or increase in the individuals' situation, which causes tension and anxiety that motive seeks to eliminate and restores individuals to a state of balance and adaptation [12]. That is to say, the function of motive is to meet the needs of individuals and maintain their balance and compatibility in the external and internal environment [5].

Ryan and Deci [5] illustrated that motive has three main functions in terms of behavior, namely: moving, activating, and directing behavior, as well as maintaining its sustainability until the need is met and the balance is 
restored. The term motivation also refers to an internal psychological state that moves individuals to conduct a particular behavior in a specific direction to achieve a certain goal. In case individuals could not achieve such a goal, they feel distressed and tensioned until achieving it $[13,14]$.

Some researchers pointed out that motivation is not an abstract that can be directly observed, but it is a condition in the human being whose existence is shown in the behavior patterns observed. Thus, several behavior patterns may be constituted of a single motive. Moreover, dividing motivation into different motives does not imply that such motives are different from each other, as it is a state of tension that makes human being active [15].

\section{B. Motivation to Learn}

Psychological studies are concerned with motivation and the factors and circumstances that keep students motivated. The topic of motivation is considered complicated in terms of diverse parties concerned, either in terms of their requirements in the classroom and the appropriate educational methods that include educational learning experiences which stimulate students to get involved in the educational learning attitude on one hand, and the different psychological trends that are dealt with in the light of the intellectual vision of motivation on the other hand, whether through behavioral, cognitive, or human trends, or through analytical school of psychology. Therefore, motivation to learn can be defined in the light of its general concept as follows:

Biehler and Snowman [16] defined learning motivation as:" The internal or external state of learners that moves their behavior and claims and which makes them continue, and keep them going towards a specific goal or purpose."

\section{The Relationship between Motivation and Academic Achievement}

Most studies point out that motivation and encouragement stimulate students to achieve. It was also pointed out that children who are raised under high parental protection, have a higher learning motivation. In addition, challenges increase their ambition, stimulate their imagination and production, and increase their academic achievement $[17,18,19]$.

On the other hand, learning motivation plays an important and influential role in raising the level of individuals performance and productivity in the various fields and activities that they experience, especially in the field of academic achievement. Moreover, differences in the academic achievement of students can be demonstrated by means of motivation level of students as most studies confirmed that the higher the level of learning motivation, the higher the academic achievement of students [20].

Academic achievement depends mainly on learning, education, orientation, and motivation. Murray [21] stated: "Motivation of learning is the constant desire to strive for success, to accomplish difficult tasks, to efficiently overcome obstacles, with the least amount of effort and time, and with the best level of learning." [22].

Furthermore, there are studies stressed the importance of motivation to learn in increasing academic achievement and success and found a fundamental relationship between motivation for learning and learning achievement [6] as motivation to learn is an internal situation of learners which moves their behavior and performance and directs them to achieve a specific goal, such as achieving the highest results that lead to success, so that success of the educational process depends on the effectiveness of the students and their motivation to learn [23]. Also, many studies claimed that student's academic achievement is important in order to enhance teaching and learning method, student needs assessment and students learning behavior [24,25].

As mentioned above, motivation is one of the most significant ways to achieve educational objectives because it is considered one of the key factors that help in gaining knowledge and understanding. It can be said that perhaps the most important principle in learning is the existence of motivation [26, 27].

\section{The Relationship between Motivation and Learning}

Motivation has a direct relationship with students behavior and their learning, as several useful impacts of motivation can be observed in students learning and behavior. Ames; Dev; Bester \& Brand; Guay, Chanal, Ratelle, Marsh, Larose and Boivin; Ghaedi \& Jam $[28,29,30,31,32]$ illustrated the relationship as follows:

- Motivation moves behavior of students towards certain goals, hence motivation affects the choices of students.

- Motivation increases initiating and persisting on activities, so it creates in them the desire to continue and to persist in the performance of tasks, when obstacles takes place or when they become frustrated while they are performing such tasks.

- Motivation assists student to process information and affects the manner and quantity of processing information. Highly motivated Students are more attentive to the teacher, and thus acquires more information in short-term memory and long-term memory. Moreover, such highly motivated students seek help from the teacher or from other sources when they are in need as they attempt to acquire more knowledge, to be more focused on meaningful learning, and not to care about simply keeping information at the deaf level.

The academic achievement of students is not recognized without understanding their motivation to learn through a framework that asserts the goals of learners. In other words, it can be said that the academic achievement of students in the classroom is an indication of many factors, some of which are related to motivation and the other factors are related to the environmental 
conditions. This study intends to discover the relationship between motivation to learn and academic achievement of Arabic school students in china because of the scarcity of such studies in this respect. It specifically recognizes the characteristics affecting academic achievement of these students by their motivation of learning and not to forget to mention the cultural differences of these students in comparison to the Chinese culture. That is why this study is considered to be as one of the most important studies.

\section{E. Aims of the Study}

- The main aim of this study is to find the relationship between motivation to learn of students of basic Arabic schools and their academic achievement.

- $\quad$ Find the values of ( $\mathrm{R}$ - square, $\beta, \mathrm{T}$ - value and Fvalue) by using regression analysis to predict the academic achievement through the motivation to learn.

- Identify whether there are any statistical significant differences between the research variables (Gender and Grade).

\section{MEthodolOGY}

\section{A. Study Group}

This correlational study covered all 242 students in the basic Arabic schools (106 males (44\%) and 136 females $(56 \%)$ for the $7^{\text {th }}, 8^{\text {th }}$ and $9^{\text {th }}$ Grades in China. The age of the sample ranged from 13 to 16 years old. The random sampling technique was adopted to select the sample study.

\section{B. Tool of the Research}

The tool, which used in this study, based on many educational literatures and previous studies on the subject such as the study of Broussard and Ghenghesh [33, 34]. The exploratory study of the questionnaire has been done to verify its psychometric properties (validity and reliability) for 30 students. In order to validate the tool, it was presented to specialists and experts in the field.

Table 1. Validity of Questionnaire Items

\begin{tabular}{|c|c|c|}
\hline No & Items & $\begin{array}{l}\text { Correlation } \\
\text { Coefficient }\end{array}$ \\
\hline 1 & I always read textbook before classes & $0.521^{* *}$ \\
\hline 2 & I try to be at the level of students who are successful in their studies & $0.595^{* *}$ \\
\hline 3 & I have a strong desire to ask about topics related to school & $0.681^{* *}$ \\
\hline 4 & I carry out whatever I am asked to do in the school & $0.575^{* *}$ \\
\hline 5 & I like to get my teacher's assistance in planning to what I should do later & $0.743^{* *}$ \\
\hline 6 & I feel happy when I am in the school & $0.598^{* *}$ \\
\hline 7 & I pose questions in the class as I like to learn whatever new & $0.643^{* *}$ \\
\hline 8 & I am interested in doing my homework & $0.541^{* *}$ \\
\hline 9 & I do a lot of school activities & $0.529^{* *}$ \\
\hline 10 & I feel satisfied when I develop my school skills and information & $0.553^{* *}$ \\
\hline 11 & My passion for studying encourages me to overcome all the obstacles & $0.633^{* *}$ \\
\hline 12 & Cooperation with my colleagues while doing home works is beneficial & $0.723^{* *}$ \\
\hline 13 & I prefer to do my homework with a number of colleagues & $0.610^{* *}$ \\
\hline 14 & I do not fed up when I do my homework with my colleagues & $0.743^{* *}$ \\
\hline 15 & I can create easy friendship with colleagues at school & $0.598^{* *}$ \\
\hline 16 & My parents listen to me when I talk about my school problems & $0.643^{* *}$ \\
\hline 17 & I can pay attention to the teacher's explanation and follow up & $0.541^{* *}$ \\
\hline 18 & I face various school positions with full responsibility & $0.575^{* *}$ \\
\hline 19 & Revision with my colleagues at school enables me to have good scores & $0.811^{* *}$ \\
\hline 20 & I feel happy when I am doing my home work & $0.811^{* *}$ \\
\hline 21 & I do my homework in a way that is better than my colleagues & $0.792^{* *}$ \\
\hline 22 & I make sure to have a discussion with teachers & $0.631^{* *}$ \\
\hline 23 & I hugely participate in school activities & $0.779^{* *}$ \\
\hline 24 & I prefer to pay attention and to do my homework rather than anything else & $0.795^{* *}$ \\
\hline 25 & I enjoy new ideas that I learned at school & $0.788^{* *}$ \\
\hline 26 & I like strict rules of the school & $0.575^{* *}$ \\
\hline 27 & I prefer to pay attention to my lessons on the account of any other thing & $0.811^{* *}$ \\
\hline 28 & I like a sort of a difficult homework because I feel interested to overcome difficulty & $0.743^{* *}$ \\
\hline 29 & I feel that almost all lessons provided by teacher are interesting & $0.598^{* *}$ \\
\hline 30 & I am easily convinced to participate at any new activity at school & $0.643^{* *}$ \\
\hline 31 & I like an easy assignment which I feel very certain of my ability to do & $0.541^{* *}$ \\
\hline 32 & I prefer that teachers give us easy questions that do not require thinking & $0.712^{* *}$ \\
\hline 33 & I like to complete my homework myself without assistance in order to be more independent & $0.735^{* *}$ \\
\hline 34 & I stick to the roles and behavior required by school. & $0.587^{* *}$ \\
\hline 35 & I bear school difficulties and problems that I face. & $0.634^{* *}$ \\
\hline 36 & I like to do homework that require more time & $0.579^{* *}$ \\
\hline 37 & I like difficult homework because it is a challenge for me. & $0.645^{* *}$ \\
\hline 38 & I am satisfied when I develop my school knowledge and skills & $0.743^{* *}$ \\
\hline 39 & I fulfill school assignments accurately & $0.598^{* *}$ \\
\hline 40 & I like school attitudes that teach me responsibility & $0.643^{* *}$ \\
\hline
\end{tabular}


This questionnaire consists of 40 items distributed among four dimensions: Sharing with others (items number: $2,6,12,13,14,15,16,19,21,22)$, Effectiveness (items number : 1, 3, 4, 5, 7, 10, 17, 20, 37, 38 ), Interest in school activity (items number : $8,9,11$, $23,24,25,26,29,30,32$ ), and Taking responsibility (items number :18, 27, 28, 31, 33, 34, 35, 36, 39, 40). The students specify their level of agreement over the items raised in the tool in a five-level Likert scale (always applicable, almost applicable, sometimes applicable, seldom applicable and not applicable at all). From Table 1 it is clear that all the items are statistically significant at 0.01 . The highest correlation was with the items 19,20 and $27 \mathrm{R}=0.811$ of the questionnaire (Revision with my colleagues at school enables me to have good scores, I feel happy when I am doing my home work and I prefer to pay attention to my lessons rather than doing other things) respectively. While the lowest correlation was with the first item $\mathrm{R}=0.521$ (I always read textbook before classes). This indicates the strong internal consistency of each item with the overall degree of questionnaire. The researcher recognized the cumulative scores of academic achievement of students for the last academic year 2017-2018, which was considered as one of the variables of the current study and compared to motivation to learn in the questionnaire sample of 30 students as well as the sample of the final study that consists of 242 students.

Criterion validity was also studied to find out the correlation between the student's motivation to learn and their academic achievement. The correlation value is (0.613) which indicates that the increasing in student's motivation to learn leads to the highest academic achievement of students.

Table 2. Criterion Validity of the Questionnaire

\begin{tabular}{ccc}
\hline Pearson Correlation & Motivation score & Academic Achievement Score \\
\hline Motivation score & 1 & $0.613^{* *}$ \\
Academic Achievement Score & $0.613^{* *}$ & 1 \\
Number of Students & 30 & 30 \\
\hline$(\rho<0.01) \quad$ & &
\end{tabular}

Cronbach's alpha was calculated based on the four dimensions of the tool. The Cronbach's alpha for whole dimensions was $(\alpha=0.846)$ and the Guttman Split-Half was $(0.850)$ which is suitable and acceptable ratios for the test.

Table 3. Reliability of the Questionnaire

\begin{tabular}{cccc}
\hline Dimensions & No. of Items & Cronbach's Alpha $(\alpha)$ & Guttman Split-Half \\
\hline $1^{\text {st }}$ dimension & 10 & $0.743^{* *}$ & $0.771^{* *}$ \\
$2^{\text {ed }}$ dimension & 10 & $0.677^{* *}$ & $0.723^{* *}$ \\
$3^{\text {rd }}$ dimension & 10 & $0.600^{* *}$ & $0.645^{* *}$ \\
$4^{\text {th }}$ dimension & 10 & $0.707^{* *}$ & $0.731^{* *}$ \\
Whole dimensions & 40 & $0.846^{* *}$ & $0.850^{* *}$ \\
${ }^{* * *}(\rho<0.01)$ & &
\end{tabular}

\section{RESUltS AND DISCUSSION}

Table 4 shows the correlation of the student's motivation to learn with the academic achievement. With regard to this correlation, there is a positively and significantly relationship between each dimensions of motivation to learn and academic achievement. These findings were supported by Ofori, Nsiah-Gyabaah \&
Sekyere [35] who found that there is a significant correlation between achievement and motivation scores of the students. A study by Goldberg and Cornell [36] revealed statistically significant correlation between motivation and academic achievement. Mnyandu [37] found a significant positive correlation between motivation and learners' achievement.

Table 4. Correlation among Dimensions of Motivation to learn and the Academic Achievement

\begin{tabular}{|c|c|c|c|c|c|c|}
\hline Variables & $\begin{array}{c}\text { Sharing with } \\
\text { others }\end{array}$ & Effectiveness & $\begin{array}{c}\text { Interest in } \\
\text { school } \\
\text { activity }\end{array}$ & $\begin{array}{c}\text { Take } \\
\text { responsibility }\end{array}$ & $\begin{array}{c}\text { Academic } \\
\text { Achievement }\end{array}$ & $\begin{array}{c}\text { Whole } \\
\text { Dimensions }\end{array}$ \\
\hline Sharing with others & - & & & & & \\
\hline Effectiveness & $.472^{* *}$ & - & & & & \\
\hline Interest in school activity & $.401^{* *}$ & $.391^{* *}$ & - & & & \\
\hline Taking responsibility & $.420^{* *}$ & $.483^{* *}$ & $.451^{* *}$ & - & & \\
\hline Academic Achievement & $.682^{* *}$ & $.507^{* *}$ & $.591^{* *}$ & $.542^{* *}$ & - & \\
\hline Whole Dimensions & $.743^{* *}$ & $.806^{* *}$ & $.720^{* *}$ & $.766^{* *}$ & $.755^{* *}$ & - \\
\hline
\end{tabular}


Table 5 shows the mean score of academic achievement $(\mathrm{M}=79.314, \mathrm{SD}=9.091)$ and the mean scores for each of the four dimensions of motivation to learn which ranged from (36.099 to 39.645). The mean of the whole motivation dimensions was $(\mathrm{M}=151.124, \mathrm{SD}$ $=21.129$ ), which indicates that students were motivated to learn and they displayed a high level of interest in school activity $(\mathrm{M}=39.645, \mathrm{SD}=6.400)$.

Table 5. Mean and Standard Deviation of Motivation to learn and the Academic Achievement

\begin{tabular}{ccc}
\hline Variables & \multicolumn{2}{c}{ Number of Participants $=242$} \\
\cline { 2 - 3 } & Mean & SD \\
\hline Academic Achievement & 79.314 & 9.091 \\
Sharing with others & 38.207 & 6.461 \\
Effectiveness & 37.174 & 8.295 \\
Interest in school activity & 39.645 & 6.400 \\
Taking responsibility & 36.099 & 6.577 \\
Motivation to learn (whole dimensions) & & 21.129
\end{tabular}

In order to predict the academic achievement by motivation to learn, the regression analysis was used. The four dimensions of motivation to learn are tested as shown in (Table 6) and Fig 1,2,3,4,5. The results revealed that there is a positive relation between motivation to learn with academic achievement and the relationship is statistically significant. The $F$ value clarifies the significance between the whole dimensions of motivation to learn and academic achievement $(\mathrm{R}$ Square $=0.570),(\beta=0.755)$ and $(F$ value $=318.349)$. So, it is possible to predict the academic achievement scores through the student's motivation to learn. The values of the first dimension "sharing with others" is ( $\mathrm{R}$ Square = $0.465),(\beta=0.682)$ and $(\mathrm{T}$ value $=14.449)$. The second dimension "effectiveness" $(\mathrm{R}$ Square $=0.257),(\beta=$ 0.507 ) and ( $\mathrm{T}$ value $=9.108)$. The third dimension "interest in school activity" $(\mathrm{R}$ Square $=0.349),(\beta=$ $0.591)$ and $(\mathrm{T}$ value $=11.338)$. The fourth dimension "taking responsibility" $(\mathrm{R}$ Square $=0.294),(\beta=0.542)$ and $(\mathrm{T}$ value $=9.989)$. From $($ Table 6$)$ below $\mathrm{T}$ value clarifies the significance between each dimension of motivation to learn and academic achievement. So, there is a noticeable effect of motivation with all its dimensions on the academic achievement.

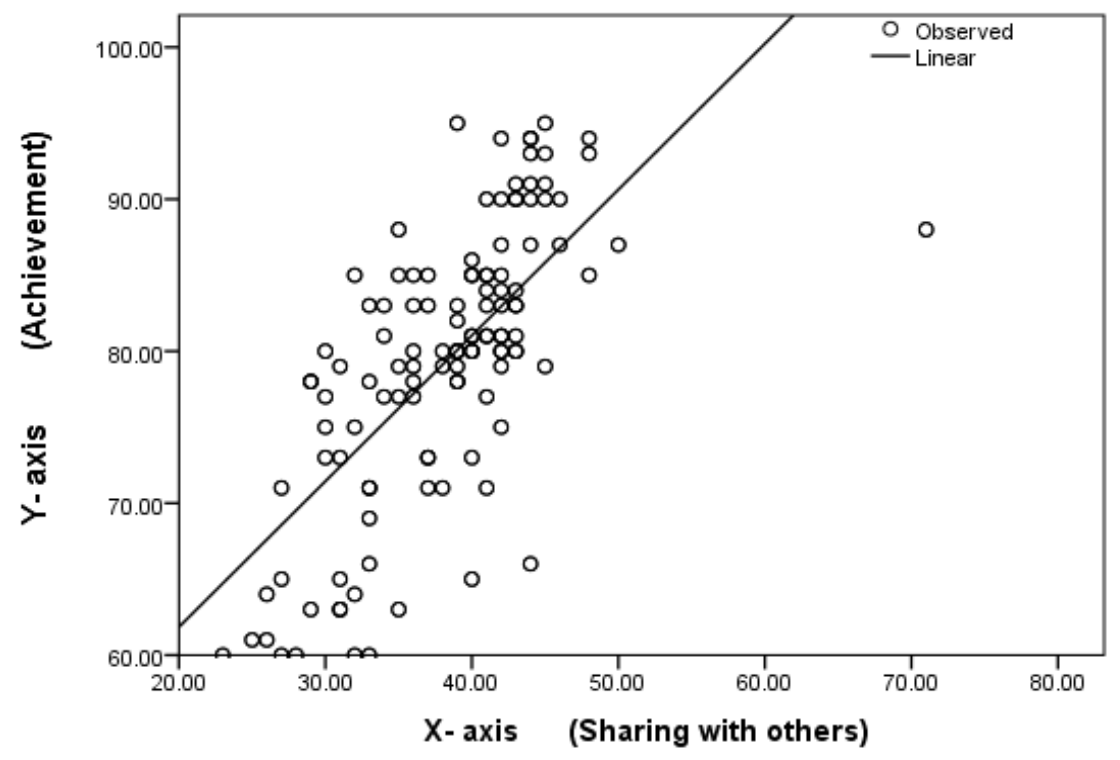

Fig.1. Prediction of the Academic Achievement through the Sharing with others 


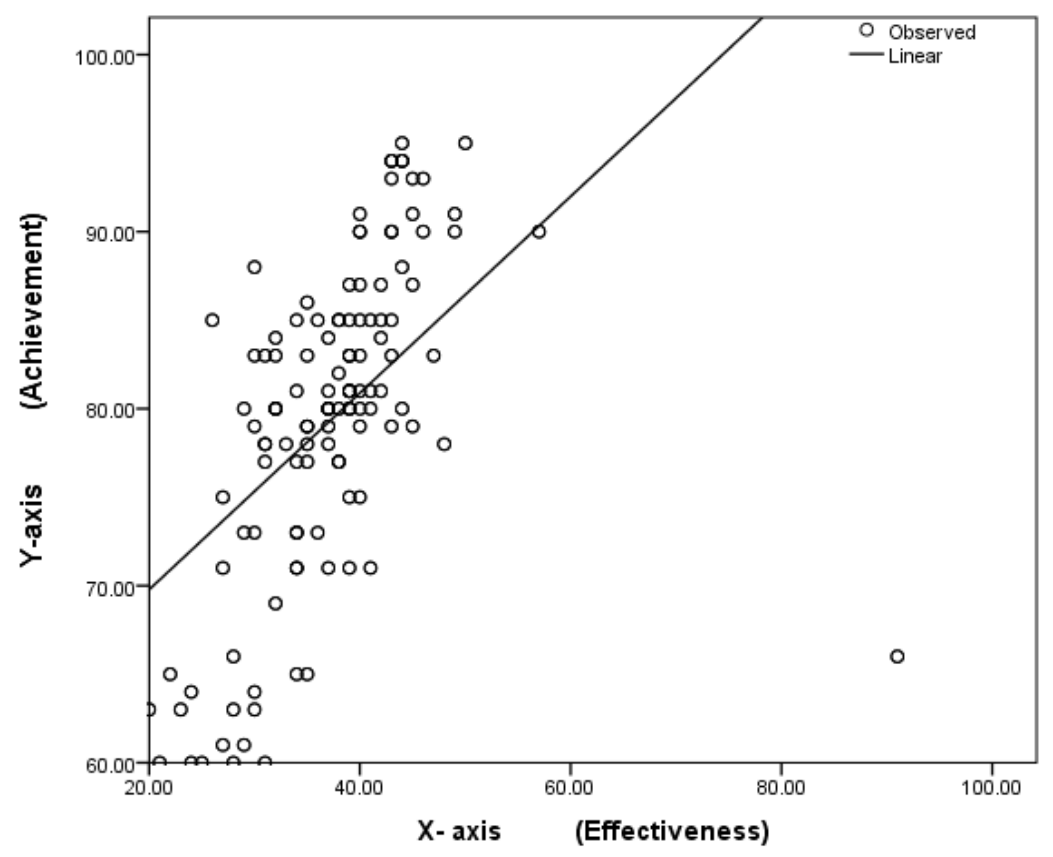

Fig.2. Prediction of the Academic achievement through effectiveness

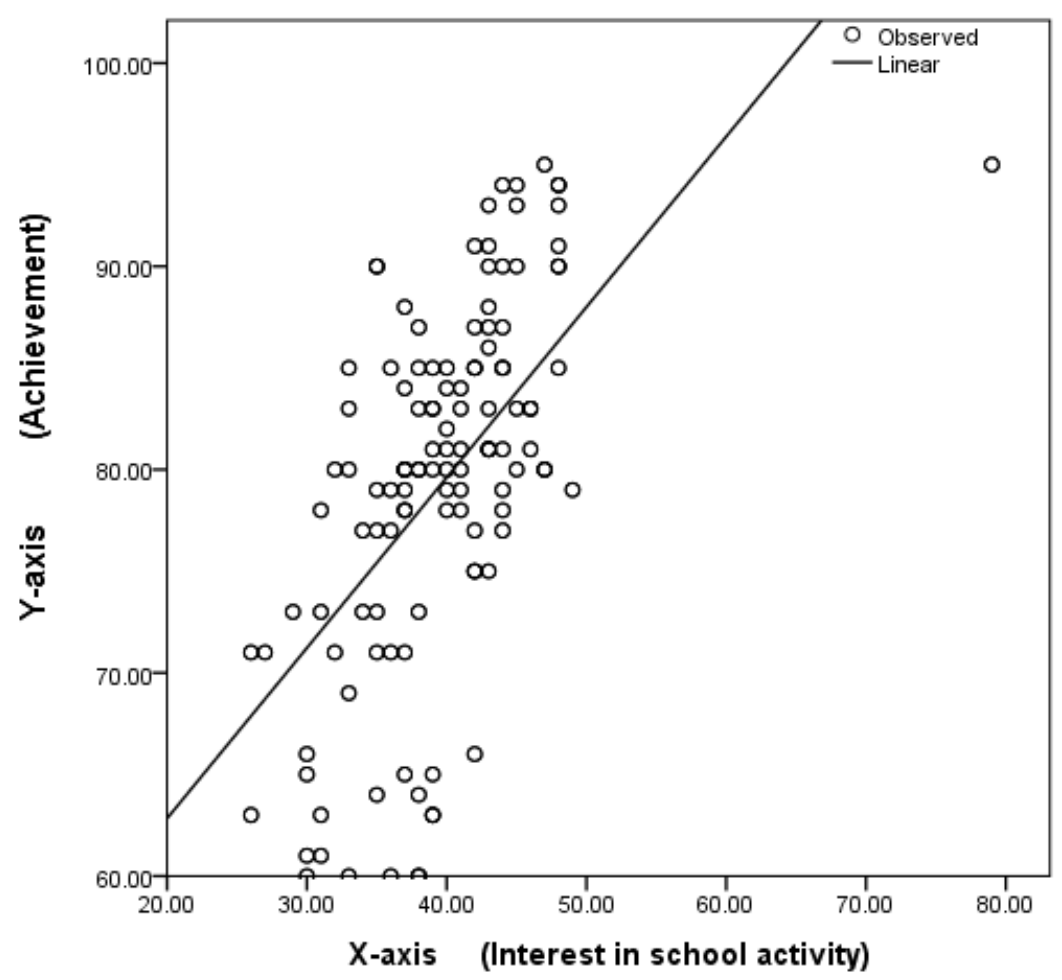

Fig. 3. Prediction of the Academic Achievement through the Interest in School Activity 


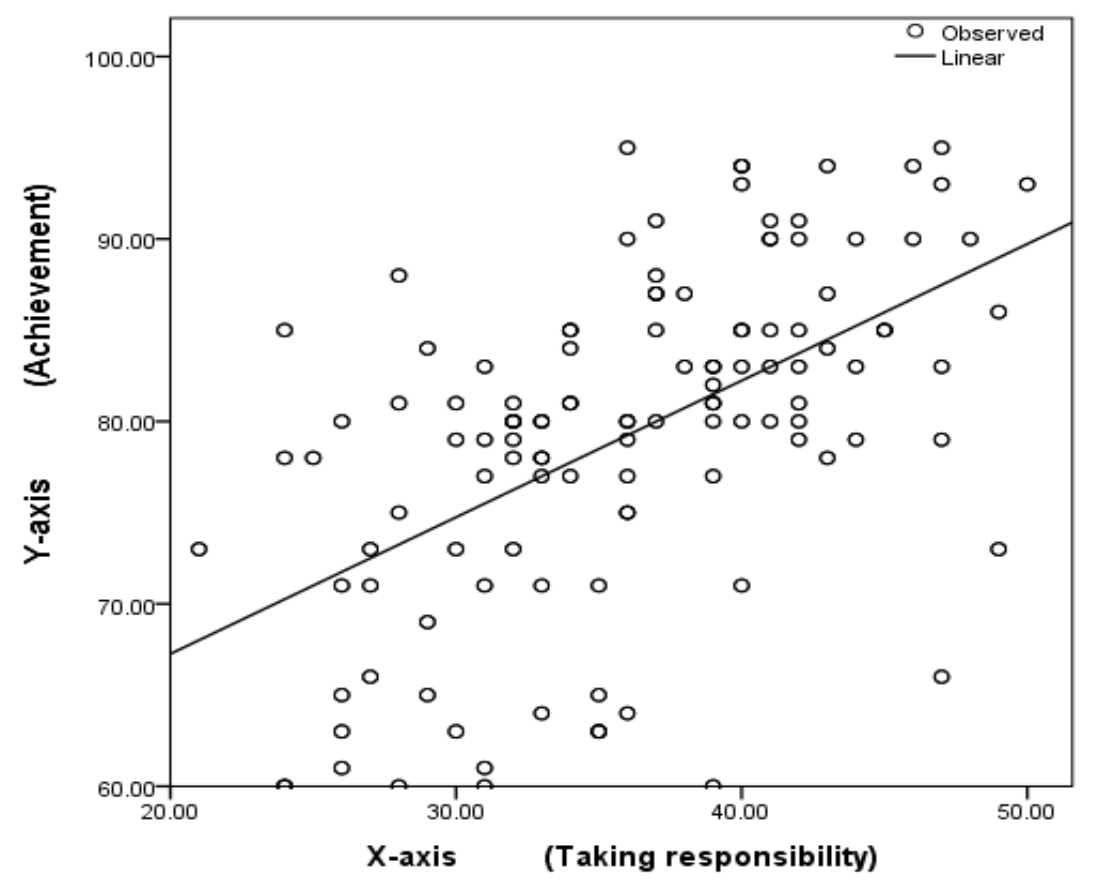

Fig.4. Prediction of the Academic Achievement through Taking Responsibility

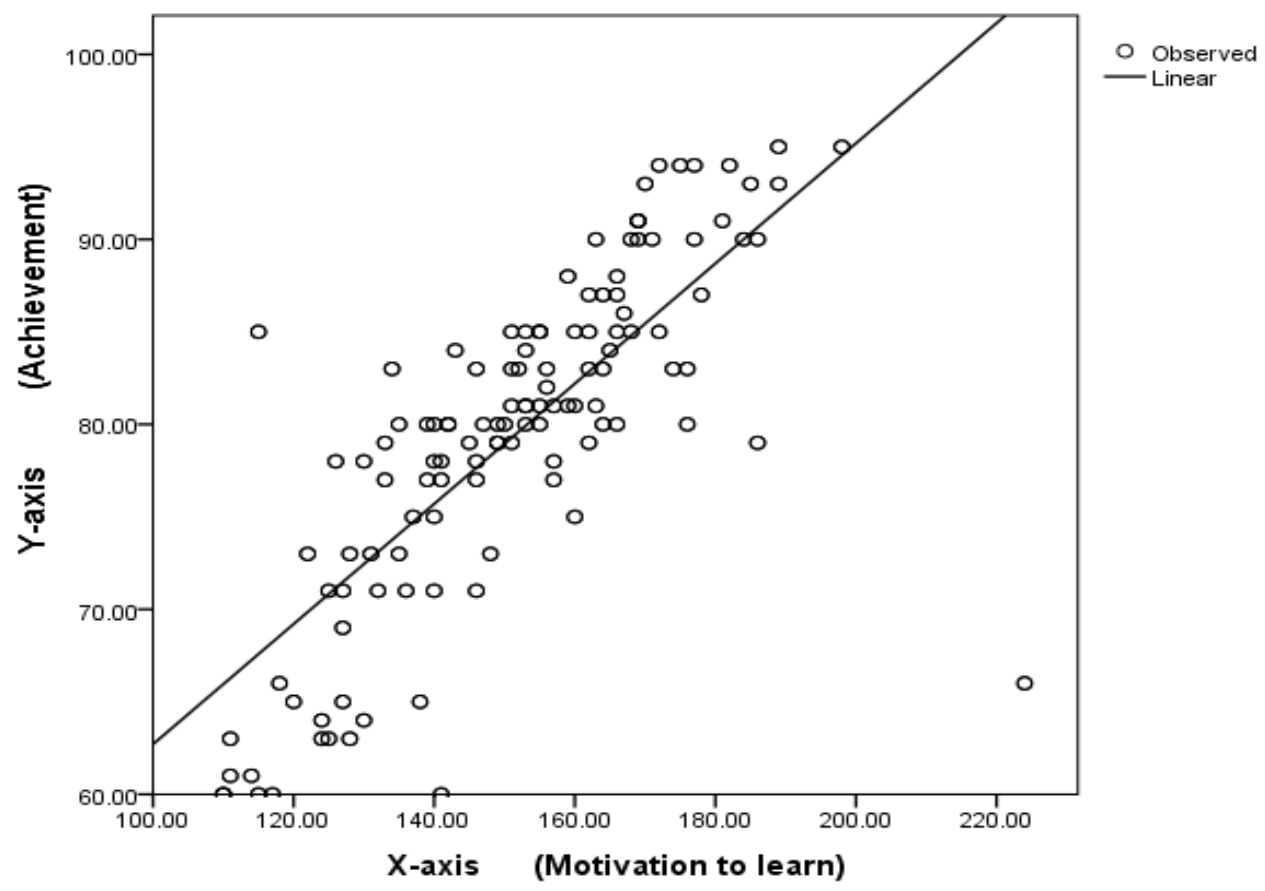

Fig.5. Prediction of the Academic Achievement through motivation to learn (whole dimensions)

Table 6. Regression Analysis for Prediction the Academic Achievement on the basis of Motivation to learn

\begin{tabular}{lccccc}
\hline \multicolumn{1}{c}{ Variables } & R Square & $\beta$ & T value & F value & $\rho$ \\
\hline Sharing with others & 0.465 & 0.682 & $14.449^{* * *}$ & - & -000 \\
Effectiveness & 0.257 & 0.507 & $9.108^{* * *}$ & .000 \\
Interest in school activity & 0.349 & 0.591 & $11.338^{* * *}$ & - & -000 \\
Taking responsibility & 0.294 & 0.542 & $9.989^{* * *}$ & - & .000 \\
Motivation to learn (whole dimensions) & 0.570 & 0.755 & - & $318.349^{* * *}$ & .000 \\
\hline$* * *$
\end{tabular}

${ }^{* * * *}(\rho<0.001)$ 
Gender differences in motivation to learn were analyzed by using independent t- test and the results are presented in (Table 7 and Fig 6). As the means indicate, both males and females have scored high level in third dimension 'Interest in school activity' but the highest level was in favor of female students. There were statistically significant gender differences among the four dimensions. This finding concurred with studies of Ergene; Jegede; Jen \& Yong; McCarthy \& Widanski; Ofori et al [38, 39, 40, 41, 35]. Awan, Noureen \& Naz [42], stated that females have been found by several studies to be more motivated than males and explained in their study that females were found to generally outperform males and that males consistently showed lower levels of academic achievement than their female counterparts. In another study of Eymur and Geban [43]. Whose aim was to examine the motivational differences between male and female students, females were found to be more motivated than males in all motivational scales. According to Brophy [44] males generally place less value on engaging in school activities than females do. Also, it is noticeable that there were statistically significant differences in motivation to learn according to gender variable as well as statistically significant differences in academic achievement of students according to the same gender variable which emphasizes the positive relationship between motivation to learn and academic achievement.

Table 7. The Difference between the Mean Scores of Academic Achievement and Motivation to learn of Male and Female Students

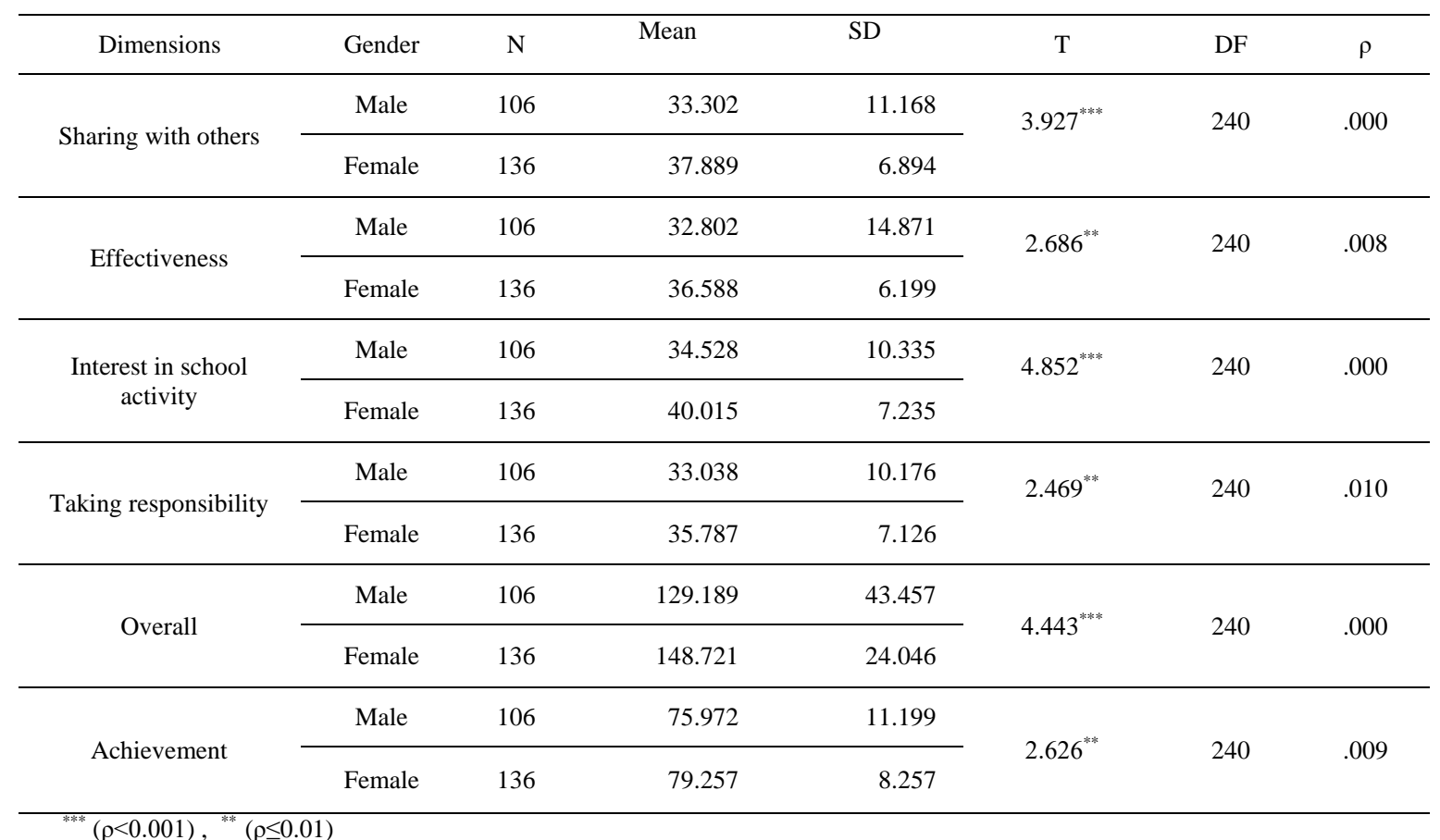

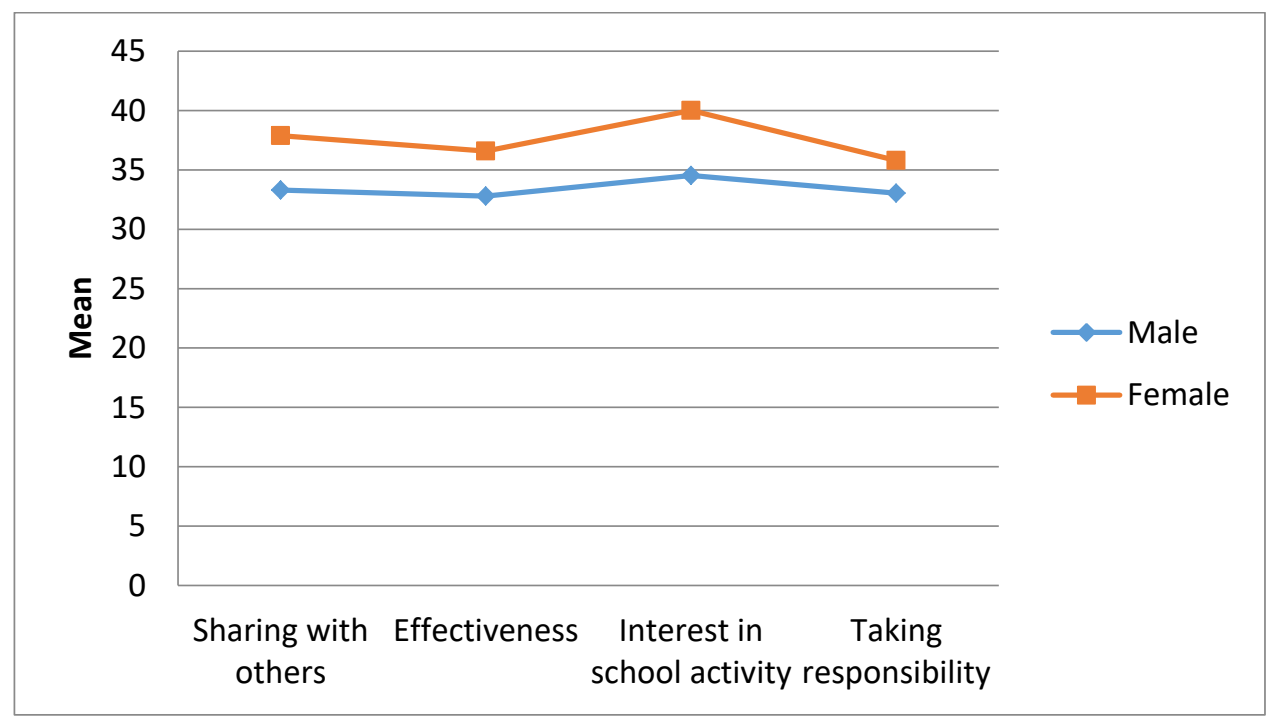

Fig.6. Means of the Four Dimensions for Gender Variable 
Table 8 and Fig 7 show the mean scores for each of the four dimensions according to grade variables. It is clearly noticed that the third dimension scored the highest mean "Interest in school activity" $(\mathrm{M}=39.645, \mathrm{SD}=6.400)$. Also, the results revealed that the eighth grade scored the highest mean $(\mathrm{M}=41.026, \mathrm{SD}=8.279)$. No statistically significant differences were found among the four dimensions according to grade variables. The results are congruent with those reported by Coleman, Galaczi \& Astruc [45] that the ANOVA analysis confirms that there are no significant differences between the grade variables. Also, these findings mirror those of Ghenghesh [34] and
Williams, Burden \& Lanvers [46] these researchers found a decrease in motivation to learn between Grades 7 and 9. In addition, Palicz [47] found that there are a certain aspects in motivation to learn and related activities of the learners seem to be changed from time to time Also, it is noticeable that there were no statistically significant differences in motivation to learn according to grade variables as well as no statistically significant differences in academic achievement of students according to grade variables which emphasize the positive relationship between motivation to learn and academic achievement.

Table 8. The Difference between the Mean Scores of Motivation to learn and Academic Achievement according to the Grade Variable

\begin{tabular}{|c|c|c|c|c|c|c|c|c|c|c|}
\hline Dimensions & Grade & $\mathrm{N}$ & Mean & SD & & $\begin{array}{l}\text { Sum of } \\
\text { Squares }\end{array}$ & $\begin{array}{c}\text { Mean } \\
\text { Square }\end{array}$ & DF & $\mathrm{F}$ & $\rho$ \\
\hline \multirow{3}{*}{$\begin{array}{l}\text { Sharing with } \\
\text { others }\end{array}$} & Seventh & 96 & 37.312 & 5.643 & $\begin{array}{l}\text { Between } \\
\text { Groups }\end{array}$ & 213.616 & 106.808 & 2 & \multirow{4}{*}{2.593} & \multirow{4}{*}{.077} \\
\hline & Eighth & 78 & 39.512 & 7.977 & $\begin{array}{l}\text { Within } \\
\text { Groups }\end{array}$ & 9846.053 & 41.197 & 239 & & \\
\hline & Ninth & 68 & 37.971 & 5.356 & \multirow{2}{*}{ Total } & \multirow{2}{*}{10059.669} & & \multirow{2}{*}{241} & & \\
\hline Total & & 242 & 38.207 & 6.461 & & & & & & \\
\hline \multirow{3}{*}{ Effectiveness } & Seventh & 96 & 36.417 & 6.964 & $\begin{array}{l}\text { Between } \\
\text { Groups }\end{array}$ & 398.369 & 199.185 & 2 & \multirow{4}{*}{2.931} & \multirow{4}{*}{.057} \\
\hline & Eighth & 78 & 39.026 & 10.456 & $\begin{array}{l}\text { Within } \\
\text { Groups }\end{array}$ & 16184.341 & 67.717 & 239 & & \\
\hline & Ninth & 68 & 36.118 & 6.867 & \multirow{2}{*}{ Total } & \multirow{2}{*}{16582.711} & & \multirow{2}{*}{241} & & \\
\hline Total & & 242 & 37.174 & 8.295 & & & & & & \\
\hline \multirow{3}{*}{$\begin{array}{c}\text { Interest in } \\
\text { school activity }\end{array}$} & Seventh & 96 & 38.792 & 5.479 & $\begin{array}{l}\text { Between } \\
\text { Groups }\end{array}$ & 228.421 & 114.210 & 2 & \multirow{4}{*}{2.831} & \multirow{4}{*}{.061} \\
\hline & Eighth & 78 & 41.026 & 8.279 & $\begin{array}{l}\text { Within } \\
\text { Groups }\end{array}$ & 9643.017 & 40.347 & 239 & & \\
\hline & Ninth & 68 & 39.2647 & 4.752 & \multirow{2}{*}{ Total } & \multirow{2}{*}{9871.438} & & \multirow{2}{*}{241} & & \\
\hline Total & & 242 & 39.645 & 6.400 & & & & & & \\
\hline \multirow{3}{*}{$\begin{array}{l}\text { Taking } \\
\text { responsibility }\end{array}$} & Seventh & 96 & 35.438 & 6.138 & $\begin{array}{l}\text { Between } \\
\text { Groups }\end{array}$ & 108.729 & 54.365 & 2 & \multirow{4}{*}{1.259} & \multirow{4}{*}{.286} \\
\hline & Eighth & 78 & 36.051 & 7.178 & $\begin{array}{l}\text { Within } \\
\text { Groups }\end{array}$ & 10316.890 & 43.167 & 239 & & \\
\hline & Ninth & 68 & 37.088 & 6.429 & \multirow{2}{*}{ Total } & \multirow{2}{*}{10425.620} & & \multirow{2}{*}{241} & & \\
\hline Total & & 242 & 36.099 & 6.577 & & & & & & \\
\hline \multirow{3}{*}{ Overall } & Seventh & 96 & 147.958 & 18.381 & $\begin{array}{l}\text { Between } \\
\text { Groups }\end{array}$ & 2567.221 & 1283.611 & 2 & \multirow{4}{*}{2.921} & \multirow{4}{*}{.056} \\
\hline & Eighth & 78 & 155.615 & 25.368 & $\begin{array}{l}\text { Within } \\
\text { Groups }\end{array}$ & 105031.060 & 439.461 & 239 & & \\
\hline & Ninth & 68 & 150.441 & 18.682 & \multirow{2}{*}{ Total } & \multirow{2}{*}{107598.281} & & \multirow{2}{*}{241} & & \\
\hline Total & & 242 & 151.124 & 21.130 & & & & & & \\
\hline \multirow{3}{*}{ achievement } & Seventh & 96 & 78.291 & 8.657 & $\begin{array}{l}\text { Between } \\
\text { Groups }\end{array}$ & 227.309 & 113.655 & 2 & & \\
\hline & Eighth & 78 & 80.590 & 9.741 & $\begin{array}{l}\text { Within } \\
\text { Groups }\end{array}$ & 19688.827 & 82.380 & 239 & 1.380 & .254 \\
\hline & Ninth & 68 & 79.294 & 8.862 & & 1001612 & & 241 & & \\
\hline Total & & 242 & 79.314 & 9.091 & Total & 19916.132 & & 241 & & \\
\hline
\end{tabular}




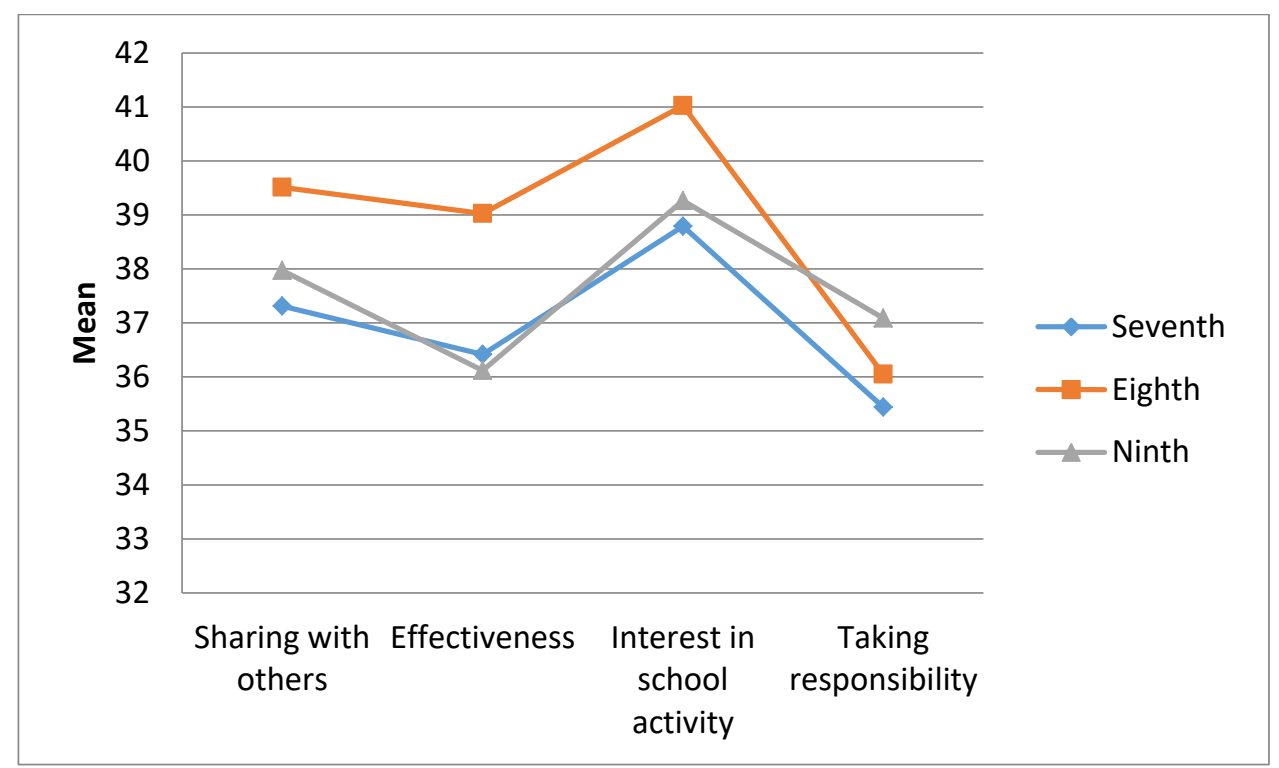

Fig.7. Means of the Four Dimensions for Grade Variable

\section{CONCLUSION}

In the current study, it has been found that there is a significant correlation between motivation to learn and academic achievement of the students' scores for the last academic year (2017-2018). The study defined the predictive value of academic achievement through motivation to learn and through each dimension of motivation specifically "sharing with others", "Effectiveness", "Interest in school activity" and "Taking responsibility". Also, it has been recognized the characteristics affecting academic achievement of these students by their motivation of learning. The study emphasizes that there are motives, which provide students with the needed strength to use the best methods to achieve the maximum potential to improve their scientific performance. The results revealed that the third dimension "Interest in school activity" was the most motivated for students (grade eighth).

\section{REFERENCES}

[1] E. Deci, R. Ryan, "Self-determination theory: a macrotheory of human motivation, development and health", Canadian Psychology, vol. 49, no. 3, pp. 182-185, 2008. https://doi.10.1037/a0012801

[2] A. Bueschel, "Listening to Students About Learning. California: The Carnegie Foundation for the Advancement of Teaching" 2008.

[3] M.Gagne, "The role of autonomy support and autonomy orientation in pro-social behavior engagement", Motivation and Emotion, vol. 27, no. 3, pp. 199-223, 2003.

[4] E. Deci, R. Vallerand, L. Pelletier, R. Ryan, "Motivation and education: the self - determination perspective", Educational Psychologist, vol.26, no. 384, 325 - 246, 1991.

[5] R. Ryan, E. Deci, "Intrinsic and extrinsic motivations: Classic definitions and new directions", Contemporary Educational Psychology, vol. 25, pp. 54-67, 2000. https://doi:10.1006/ceps.1999.1020
[6] F. Koca, "Motivation to learn and teacher-student relationship", Journal of International Education and Leadership, vol. 6, no. 2, 2016.

[7] R. Clement, Z. Dornyei, K. Noels, "Motivation, selfconfidence, and group cohesion in the foreign language classroom", Language Learning, vol. 44, no. 3, pp. 417 448, 1994.

[8] T. Seifert, "Understanding student motivation", Educational Research, vol. 46, no. 2, pp. 137-149, 2004. https://doi.org/10.1080/0013188042000222421

[9] Z. Dornyei, "Creating a motivating classroom environment", New York: New York: Springer ScienceBusiness Media, Inc, 2007.

[10] J. Bradley, P. Conway, "A dual step transfer model: Sport and non-sport extracurricular activities and the enhancement of academic achievement", British Educational Research Journal, vol. 2, no.4, pp. 703-728, 2016. https://doi.org/10.1002/berj.3232

[11] E. Mensah, K. Tawiah, "Employee Motivation and Work Performance: A comparative study of mining companies in Ghana", Journal of Industrial Engineering and Management, vol.9, no. 2, pp. 255-309, 2016 http://dx.doi.org/10.3926/jiem. 1530

[12] C. Dweck, "Self-theories. Their role in motivation. Personality and development", New York: Psychology Press, 1999.

[13] S. Aftab, S. Riaz, S. "Impact of grade sensitivity on learning motivation and academic performance", International Journal of Educational and Pedagogical Sciences, vol.10, no. 7, 2016. https://doi:10.1999/13076892/53128

[14] E. Kyndt, F. Dochy, K. Struyven, E. Cascallar, "The direct and indirect effect of motivation for learning on students' approaches to learning through the perceptions of workload and task complexity", Higher Education Research \& Development, vol. 30, no. 2, pp. 135-150, 2011. https://doi.org/10.1080/07294360.2010.501329

[15] F. Guay, "The virtue of culture in understanding motivation at school: Commentary on the special issue on culture and motivation", British Journal of Educational Psychology, vol. 68, no. 1, pp. 154-160, 2016. https://doi.org/10.1111/bjep.12105 
[16] R. Biehler, J. Snowman, "Psychology applied to teaching (7th ed.)", Boston: Houghton Mifflin Company, 1993.

[17] S. Batchelor, "Relationships Between Parent Involvement and the Academic Achievement of Disadvantaged Children : What Matters? For Whom Does it Matter? How Does it Work? ", PhD dissertation. Australia: Griffith University, 2013.

[18] L. Hornstra, M. Majoor, T. Peetsma, "Achievement goal profiles and developments in effort and achievement in upper elementary school", British Journal of Educational Psychology, vol. 87no. 4, pp. 606-629, 2017. https://doi.org/10.1111/bjep.12167

[19] J. Hughes, O. Kwok, "Influence of student-teacher and parent-teacher relationships on lower achieving readers' engagement and achievement in the primary grades", Journal of Education Psychology, vol. 99, no. 1, pp. 395, 2007. https://doi10.1037/0022-0663.99.1.39

[20] I. Naile, J. Selesho, "The role of leadership in employee motivation", Mediterranean Journal of Social Sciences, vol. 5, no.3, 2014. http://dx.doi.10.5901/mjss.2014.v5n3p175

[21] H. Murray, "Explorations in personality", New York: Oxford University Press, 1938.

[22] K. Murayama, A. Elliot, "The Joint influence of personal achievement goals and classroom goal structures on achievement-relevant outcomes", Journal of Educational Psychology, vol.101, no. 2, pp. 432- 447, 2009. http://dx.doi.org/10.1037/a0014221

[23] K. Singh, "Study of achievement motivation in relation to academic achievement of students", International Journal of Educational Planning \& Administration, vol.1, no. 2, pp. 161-171, 2011. https://www.ripublication.com/ijepa.htm

[24] L. Affendey, I. Paris, N. Mustapha, MD. Sulaiman Z. Muda, "Ranking of Influencing Factors in Predicting Students' Academic Performance", Information Technology Journal, vol. 9, no. 4, pp. 832-837, 2010.

[25] D. Delen, "A comparative analysis of machine learning techniques for student retention management", Decision Support Systems, no.49, pp. $498-506,2010$. DOI: $10.1016 /$ j.dss.2010.06.003

[26] G. Bossaert, E. Doumen, K. Buyse, Verschueren, "Predicting students academic achievement after the transition to first grade: A two-year longitudinal study". Journal of Applied Developmental Psychology, vol. 32, pp. $\quad 47-57$.

2011. https://doi:10.1016/j.appdev.2010.12.002

[27] S. Broussard, M. Garrison, "The Relationship Between Classroom Motivation and Academic Achievement in Elementary-School-Aged Children", Family and consumer sciences research journal, vol. 3, pp. 106-120, 2004

[28] C. Ames, "Classrooms: goals, structures, and student motivation", Journal of Educational Psychology, vol. 84, no. 3, pp. 261-271, 1992. Accessed 18 Dec 1991.

[29] P. Dev, "Intrinsic motivation and academic achievement: What does their relationship imply for the classroom teacher?", Remedial and Special Education, vol. 18, no. 1, pp. 12-19, 1997. https://doi.org/10.1177/074193259701800104

[30] G. Bester, L. Brand, "The effect of technology on learner attention and achievement in the classroom", South African Journal of Education, vol. 33, no. 2, 2013. https://doi:10.15700/saje.v33n2a405

[31] F. Guay, J. Chanal, CF. Ratelle, HW. Marsh, S. Larose, M. Boivin, "Intrinsic, identified, and controlled types of motivation for school subjects in young elementary school children", British Journal of Educational Psychology, vol. 80, no. 4, pp. 711-735, 2010. https://doi.10.1348/000709910X499084

[32] Z. Ghaedi, B. Jam, "Relationship between learning styles and motivation for higher education in EFL students", Theory and Practice in Language Studies, vol 4, no.6, pp 1232-1237, 2014. https://doi:10.4304/tpls.4.6.1232-1237

[33] S. Broussard, "The relationship between classroom motivation and academic achievement in first and third graders", MSc dissertation. USA: Louisiana State University, 2002 .

[34] P. Ghenghesh, "The Motivation of L2 learners: Does it decrease with age?", English Language Teaching, vol.3, no. 1 , pp. 128-141, 2010.

[35] A. Ofori, E. Nsiah-Gyabaah, A. Sekyere, "Relationship between motivation, academic self-concept and academic achievement amongst students at a Ghanaian technical university", International Journal of Human Resource Studies, vol. 7, no. 1, 2017.

[36] M. Goldberg, D. Cornell, D "The influence of intrinsic motivation and self-concept on academic achievement in second-and third-grade students", Journal for the Education of the Gifted, no. 2, pp. 179-205, 1998. http://dx.doi.org/10.1177/016235329802100204

[37] P. Mnyandu, "The relations between self-determination, achievement motivation and academic achievement", MEd Dissertation. Pretoria, University of South Africa, 2001.

[38] T. Ergene, “ The relationships among test anxiety, study habits, achievement, motivation and academic performance among Turkish high school students", Education and Science, vol.36, no. 160, pp. 320-330, 2011.

[39] S. Jegede, "Students' anxiety towards the learning of chemistry in some Nigerian secondary schools", Educational Research and Review, vol. 2, no. 7, pp. 193197, 2007.

[40] C. Jen, B. Yong, "Secondary school students' motivation and achievement in combined science", US-China Education Review, vol. 3, no. 4, pp. 213-228, 2013.

[41] W. McCarthy, B. Widanski, "Assessment of chemistry anxiety in a two year college" Journal of Chemical Education, vol. 86, no. 12, pp. 1447-1449, 2009

[42] R. Awan, I. Noureen, A. Naz, "A study of relationship between achievement motivation, self-concept and achievement in English and Mathematics at secondary level", International Education Studies, vol.4, no. 3, pp. 72-79, 2011. https://doi:10.5539/ies.v4n3p72

[43] G. Eymur, O. Geban, "An investigation of the relationship between motivation and academic achievement of preservice Chemistry teachers. Education and Science", vol.36, no. 161, pp. 246-255, 2011.

[44] L. Brophy, "Motivating students to learn", New Jersey: Lawrence Erlbaum Associates. 1998.

[45] J. Coleman, A. Galaczi, L. Astruc, "Motivation of UK school pupils towards foreign languages: a large-scale survey at Key Stage 3", Language Learning Journal, vol. 35, no. 2, pp. 245-280, 2007. https://doi.org/10.1080/09571730701599252

[46] M. Williams, R Burden, V. Lanvers, "French is the language of love and stuff': Student perceptions of issues related to motivation in learning a foreign language", British Educational Research Journal, vol.28, no. 4, pp. 503-28, 2002. https://doi.10.1080/0141192022000005805

[47] E. Palicz, "Motivation to learn English in a bilingual school context" MSc dissertation. Budapest: Eotvos University, 1994. 


\section{Authors' Profiles}

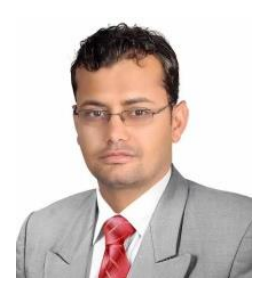

Abdo Hasan Al-Qadri was born in Yemen in 1984. He graduated from Faculty of Education of Sana'a University in 2006. He holds a MA degree in Psychological and Educational measurement and evaluation from Sana'a University in 2013. He is a Lecturer at Hodaidah University. He is currently a $\mathrm{PhD}$ student at Shaanxi Normal University- China. He worked as a trainer in the area of how to build a psychological standards and achievement tests in some Yemeni universities and schools. $\mathrm{He}$ worked as well as a consultant to the Social Fund for Development (YEMEN) in assessing the performance of teachers and adapting intelligence tests and educational difficulties. His research interest includes Educational Psychology mainly the preparation of psychological tests.

Contact info:

Email:Lubna23112015@outlook.com

Phone Number:

0086-1869187 7691

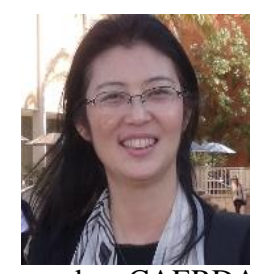

Wei Zhao'Bio was born in P.R. China in 1965, a former Associate Dean of School of Education at Shaanxi Normal University. Now, She is a professor of Educational Psychology Advisor to Ph.D students and conducting research mainly on Learning Disabilities. She is an AERA member CAERDA (Chinese American Educational Research and Development Association) member, and OMPE member in China. Zhao holds a Bachelor and a Master Degrees of School Education and Comparative Education in Shaanxi Normal University, Xian, China in 1990s, Zhao received a Ph.D degree in Educational Psychology and Special Education from East China Normal University in Shanghai, China and UBC in Canada in 2004. Her specialization is on Learning Disabilities in both Chinese and English. She has conducted more than ten national research projects on Learning disabilities, Language acquisition in early age and English Immersion teaching, such as A Research on Cognitive Mechanism of Early Childhood's Written Language Learning, Cognitive Assessment System Development of Chinese Learning Disabilities and its educational Intervention, From image to text, Research on children's written language acquisition, etc . and had published more than 40 academic papers and books, such as About the Empirical Research and Theoretical Analysis of Cognitive Process in Reading and Reading Difficulties, Cognition Processing of Reading from cross-linguistic studies, etc. She has been invited, as an External Examiner of M.A. in Early Childhood Education program, by The Chinese University of Hong Kong, Invited by Bureau of Educational and Cultural Affairs in the United States Department of State as IVLP (International Visitor Leadership Program) to visit schools and educational institutions in Washington DC, New York, Cleveland, Ohio, Atlanta Georgia and San Francisco, California. She also has been invited to give speeches at conferences in mainland China、Taiwan and Macao, etc.

\section{Contact info:}

Email:wzhao@email.arizona.edu

Phone Number: 029-4988-548-520

How to cite this paper: Abdo Hasan AL-Qadri, Zhao Wei, "Motivation to Learn and its Relationship to Academic Achievement among Students of basic Arabic Schools in China", International Journal of Modern Education and Computer Science(IJMECS), Vol.11, No.4, pp. 1-12, 2019.DOI: 10.5815/ijmecs.2019.04.01 